UC-41 and UC-71

Reporting Date: April 1974

Issued: May 1974

\title{
Shipping Container for Plutonium-238 as Fissile Material Class 1
}

Repcrt by

Horace E. Noyes

Work done by

J. N. P. Lawrence

David R. Smith

Thomas K. Keenan

Richard W. Andrae 
This report was prepared as an account of work sponsored by the United States Government. Neither the United States nor the United States Atomic Energy Commission, nor any of their employees, nor any oi their contractors, subcontractors, or their employees, makes any warranty, express or implied, or assumes any legal liability or responsibility for the accuracy, completeness or usefulness of any information, apparatus, product or process diselosed, or represents that its use would not infringe privately owned rights.

In the interest of prompt distribution, this LAMS report was not edited by the Technical Information stafi.

Printed in the United States of America. Available from

National Technical Information Service

U.S. Deparment of Commerce

5285 Porl Royal Road

Springlield, Virginia 22151

Price: Printed Copy \$4.00 Microfiche $\$ 1.45$ 


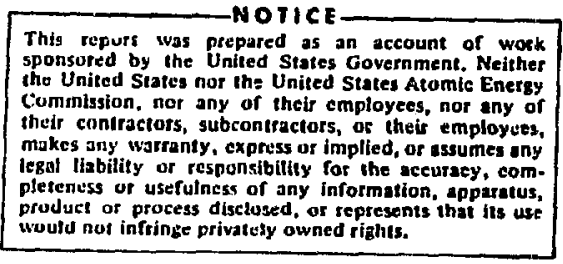

\title{
SHIPPING CONTAINER FOR PLUTONIUM-238 \\ AS FISSILE MATERIAL CLASS 1
}

by

Horace E. Noyes

\begin{abstract}
The stainlens stool shipping container is a small, right cylindrical assembly approximately $46 \mathrm{~cm}$ in diametor and $50 \mathrm{~cm}$ high, weighing approximately $91 \mathrm{~kg}$. Access to the inner container is through a series of bolted flanges. The source material within the inner cavity must be doubly encapsulated. The contenis must not exceed $720 \mathrm{~g}$ plutonium (oxide or metal), or be so reduced in quentity so an to not exceed the legally applicable external radiation limits at contact and at $1 \mathrm{~m}$.
\end{abstract}

\section{PLUTONIUM SHIPPING CONTAINER ASSEMBLY DESIGN CRITERIA}

The Los Alamos Scientitic Laboratory (LASL) has been involved in a contractural research and dovelopment program on plutonium-238 fuels, which includes preparing and characterizing candidate fuel forms for various tests and developing prototypes. As it became necessary to ship experimental specimens to other installations, a container was designed that would meet the requiremenls of AEC Manual Chapter 0529 and related regulations and provide for dissipation of the internal heat generated. The assembly consists of an inner and outer container, with powdered iron used for padding in the inner container to enhance the heat transfer out of the container. The outer container is equipped with heat dissipating fins, and a personnel shield is provided prohibiting direct contact with the surface of the container.

\section{STRUCTURAL ANALYSIS}

The structural analysis of the shipping container is attached as Appendix A.

\section{QUALITY ASSURANCE}

Quality assurance specifications, including welding specifications, are attached as Appendix B.

\section{U. S. ATOMIC ENERGY COMMISSION APPROVAL}

Certification of Approval, issued by the Operational Safety Division, Albuquerque Operations Office, USAEC, identified as AEC.ALUSA/6286/BLF, is attached as Appendix C.

\section{CONTAINER DRAWINGS}

LASL drawings ENG-E-324,D-1 through D-4 are attached as Appendix D. 
STRUCTURAL ANALYSIS OF SHIPPING CONTAINER

FOR PLUTONIUM-238

\section{Introduction}

This section presents the structural anaiysis of a proposed shipping container for use with plutonium-238. The analysis is in compliance with Section II (packaging standards) of Chapter 0529 (Saifety stanciards for the Packaging of Radioactive and Fjssile Materials) of USAEC Manual.

Comments and, in some cases, an ant lysis-sumnary are given for each applicable paragraph of Section II of AECM 0529. The actual analysis 1 s at the end and is identifi.. by the same paragraph number. 


\section{PLUTONIUM-238 SHIPPING CONTAINER \\ (Numbers Reference AECM Chap. 0529)}

II.A.1. The radioactive material is clad. The capsule stack is encased in approximately 1/2-inch of iron filings. These iron filings will alloy with any ${ }^{238}$ Pu which could escape from a capsule and prevent spreading of any ${ }^{238} \mathrm{Pu}$ within the container. Package components, with the exception of the iron filings, are selected of materials not subject to corrosive or galvanic action.

II.A.2. The positive closure device consists of multiple screws and safety wire seal.

II.A.3.a. The contalner, which w1ll be handled by fork lift or crane, has a weight of 200 lbs. Deslgn calculations indicate the capability of the handle to support three times the weight of the total load without exceeding the yield strength of the material.

II.A.3.b. Not applicable.

II.A.3.C. Not applicable.

II.A.3.d. Pailure of the IIfting device would in no way affect the containment or shielding properties of the package.

II.A.4 There are no tle down devices on this package.

II.B.1. Load resistance is more than adequate (see calculations). 
II.B.2. An external pressure of 25 psi is a trivial condition for a thick walled cylinder.

II.C. Criticality standards are discussed elsewhere.

II.D.1. Evaluation of a single package was based on calculations as required.

II.D.2. No controls by the shipper are anticipated.

II.D.3. No deviations from requirements are anticipated.

II.E. There should be no compromise of the integrity of the container or its contents as defined in Normal Conditions of Transport.

Following is a summary of the findings of the Calculations for the Normal Conditions of Transport.

1. Heat - The nature of the shipment is such that the surface temperature of the capsules must be held below $573 \mathrm{~K}$, while removing a maximum of 250 watts of heat; hence, heat removal is the critical factor in this instance. Calculations Indicate the surface temperature of the capsules reaches a maximum value of $537 \mathrm{~K}$. A personnel protection screen is necessary as surface temperatures of as high as $463 \mathrm{~K}$ are anticipated at the fin tips. The results of an actual test are shown in the calculation section.

2. Cold - Cold presents no problem for this container. Since the container will contain a heat source, it should remain warm under cold amblent conditions. 
3. Pressure - The seals used in this container are extreme pressure and temperature seals. Pressures of $1 / 2$ atmosphere are completely insignificant in this application.

4. Vibration - This shipping contalner is not susceptible to vibration damage. Sufficient vibration damping materials are incorporated in the form of insulation, steel wool, and Iron filings to protect the contents from damage.

5. Water Spray - The double sealed container should preclude entry of any molsture into the container.

6. Free Drop - A free drop of four feet is much less than the accident condition requirements and should not compromise the integrity of the container.

7. Pentration - The 520 1b-1n of energy should not exceed the elastic capability of the container and therefore would not affect the container integrity.

8. Compression stress is insignificant when compared to the yleld strength of the container material.

II.F. Calculations indicate the containment capabilities of this contalner would not be impalred when subjected to the accident conditions specified. There would be no release of radioactive materials or changes in radiation dose rates external. to 
the container. Should the container be subjected to the conditions specified in the hypothetical accident conditions, the container quite possibly should be opened only in a radiological glovebox. Following is a summary of the Hypothetical Accident Condition Calculations.

1. Free Drop - The worst damage condition resulting from a 30-foot free drop is the plastic deformation of $0.80 \mathrm{in}^{3}$ on the outer edge of the container. The inner container will serve simply as a fail safe condition in this instance. (See calculations)

2. Puncture - Conflguration of this container makes the requirements for the puncture test condition much less severe than the free drop test because the kinetic energles involved are less and, also, the fins were not used in the Free Drop Calculations.

3. Thermal - All materials required to seal the contalner were selected to function at $1500^{\circ} \mathrm{F}$ without danger of release of radioactive materlals. The materials selected all have annealing temperatures above $1500^{\circ} \mathrm{F}$. The asbestos in the stainless steel-asbestos, spiral wound gasket will decompose at $1300^{\circ} \mathrm{F}$ but the seal will remain effective until the flange foint is disassembied. The Inconel $x-750$ " 0 " ring will provide a seal on the inner container at the $1500^{\circ} \mathrm{F}$ test temperature. (See calculations)

4. Water Immersion - The dual container is designed to preclude leakage of any water 
ENG-6 Rp-8

Into the Inner container. Should any leakage into the outer container occur, the water volume would be insignificant

due to the small void to volume ratio. 


\section{II.A.3 Lifting Device Strength}

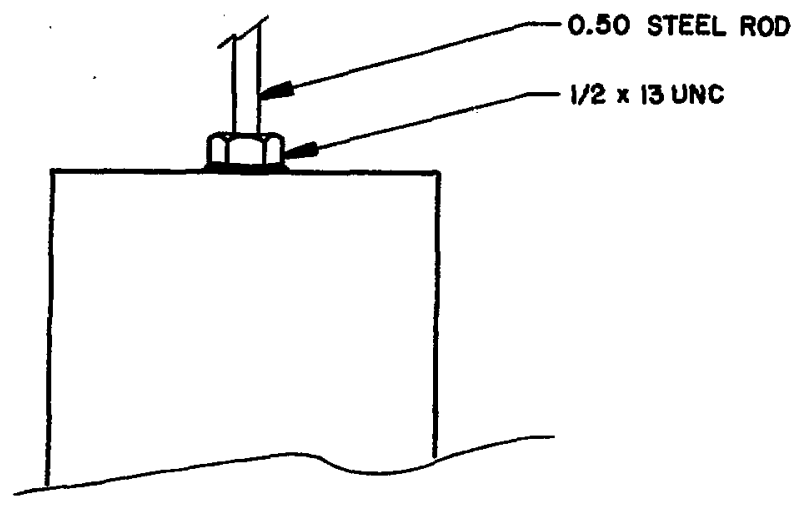

Wt assumed - 200 ibs

F.S. $=3+6001$ bs

Effective Area of $1 / 2 \times 13$ unc is 0.126 in. $^{2}$

F.S.3 $=\frac{35.000 \times 0.126}{600}=\frac{4410}{600}=\underline{7.35}$

This factor of safety indicates a strength of approximately 22 times the actual static load and 7 times the design condition which is more than adequate. 
II.B.1 Load Resistance

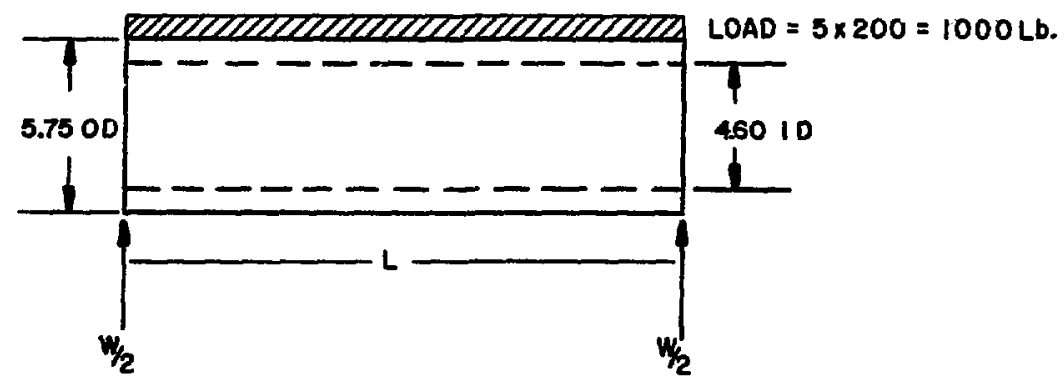

$$
\begin{aligned}
\sigma & =\frac{W L}{8 z}=\frac{1000 \times 12}{\frac{8 \pi\left(0^{4}-d^{4}\right)}{320}}=\frac{12000 \times 32 \times 5.75}{8 \pi\left(5.75^{4}-4.60^{4}\right)} \\
& =\frac{2,210,000}{25.9(1093-448)}=136 \mathrm{psi}
\end{aligned}
$$

This load stress is insignificant compared to a yield strength of 35,000 psi (347 S.s.) 
ENG-6 Rp-8

II.E.1. Normal Conditions of Transport, Heat

A thermal analysis on the $\mathrm{Pu} 238$ shipping container using heat condition of direct sunlight at an amblent temperature of $130^{\circ} \mathrm{F}(328 \mathrm{~K})$ in still air. A 250 Watt heat source was contained within the inner container. TRUMP, a heat-flow computer program, was used. A summary of the significant temperatures resulting from this condition are presented in F1g. 1 . 
I].t... . (cont..)

CME-II PLUTONIUM SHIPPING CONTAINER

Desiqn Condition - Direct sunlight at an ambient temperature of $130^{*} \mathrm{~F}$ (32aK) in still air.

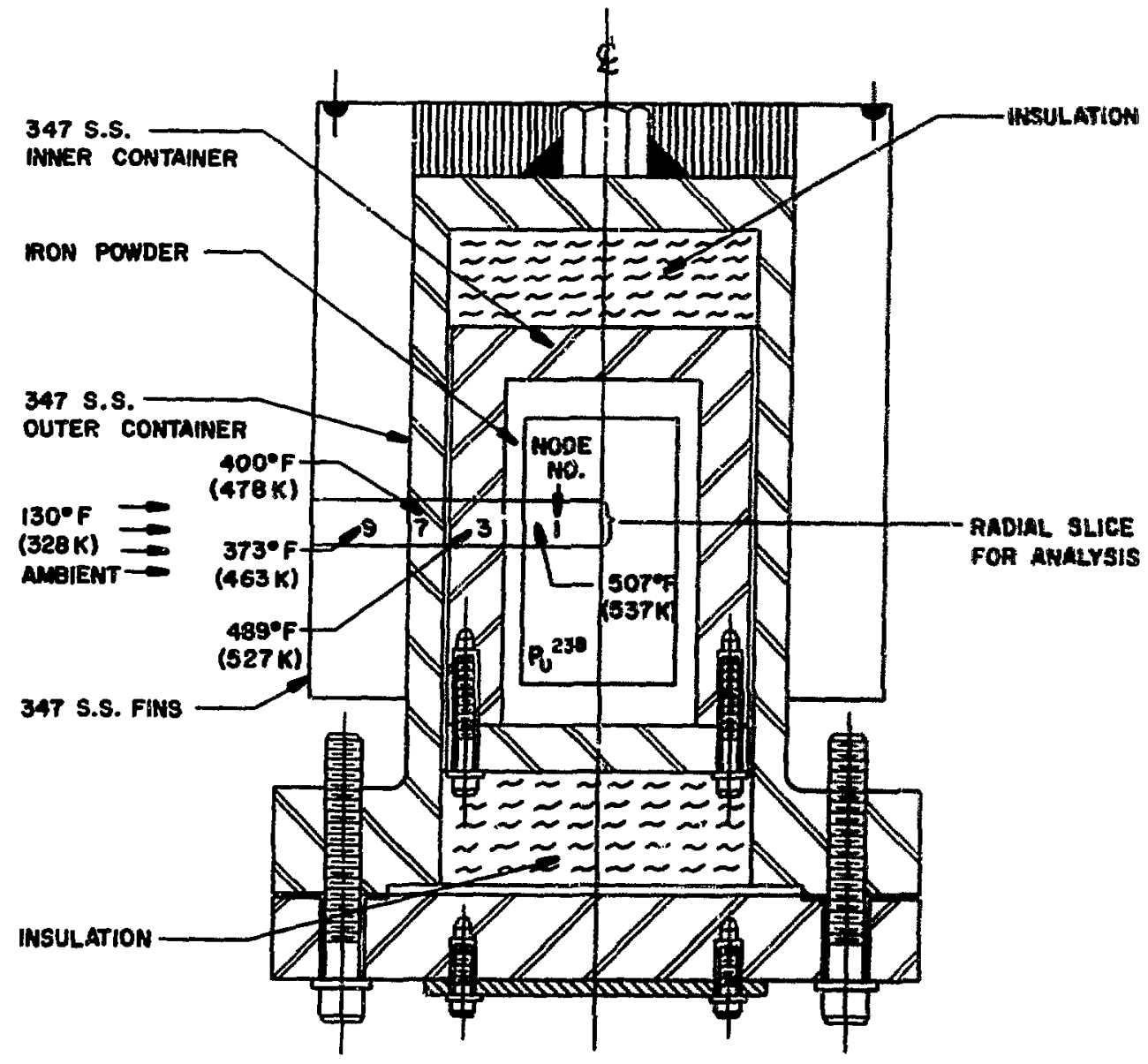

FIG. 1

Showing Materials and Temperatures 


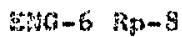

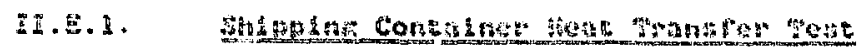

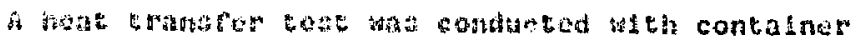

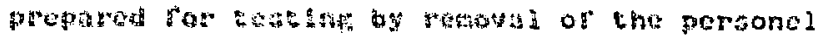

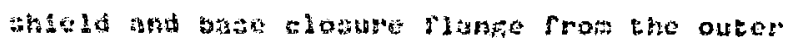

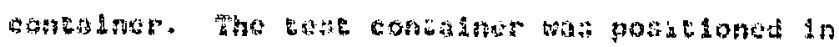

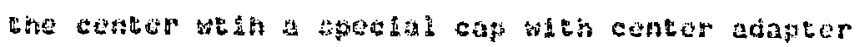

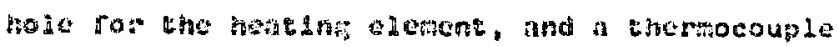

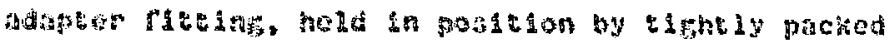

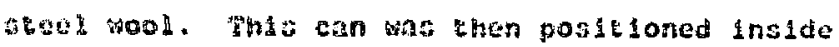
the snner cortatines or the assembly, and lowered

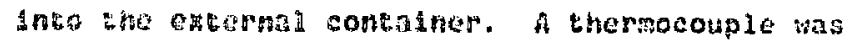

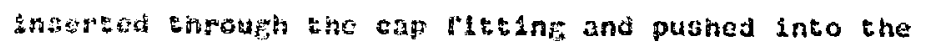

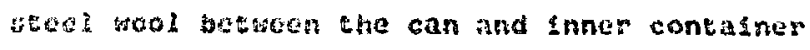
expl ard into the open and of the can. Fubberized

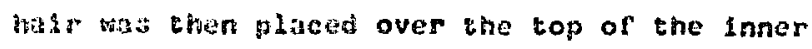
combanow and realed with platic tape. The wite lends wrate combetod to a power atat whlch was set to supply a current of 3.7 amps at 75 volts to the hoatin dement, which tad been previously calibrated to measure it's heat output.

The data and smaph of the nine hour test indlate that the inner lemperature of the container stabi13aed after approximately five hours at a temperature below the design criterla of $300 \mathrm{c}$. In actual use, the fron powder used for padding in the inner contalner Instead of the stee? wool used during this test, will Improve the heat transfer out of the container. 


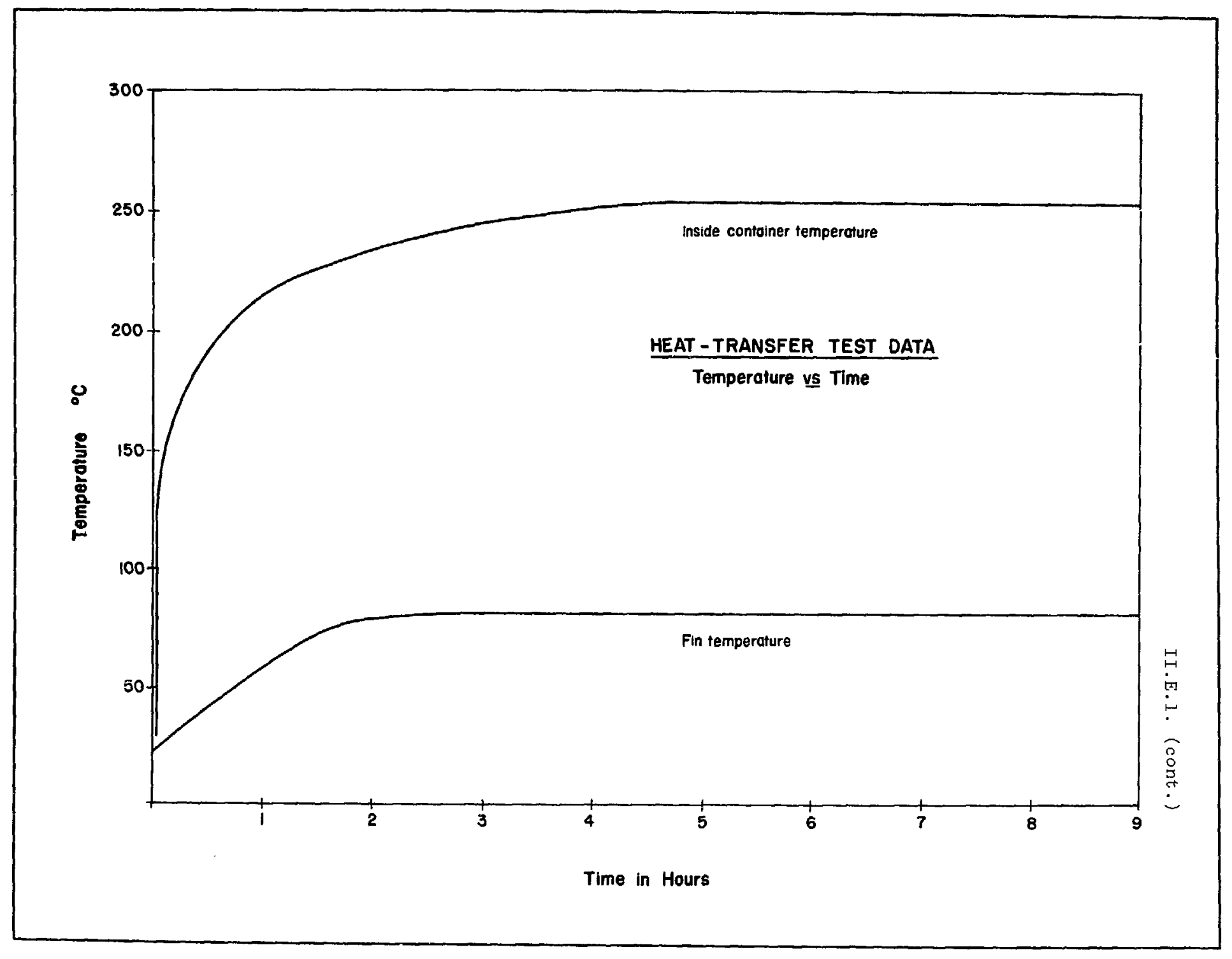


II.E. I. ( cont. )

CHB-11 SHIEPING CONTAIAER HEAT TRANSPBR TEST 2bb Job Ho. 4424-0

B. S. Foster, EkG-6

June 25, 1970

EXPERTEBNTLL DATA LOC

\begin{tabular}{|c|c|c|c|c|}
\hline $\begin{array}{l}\text { Tymo } \\
\text { Areaste }\end{array}$ & $\left|\begin{array}{c}\text { Instde Tenp } \\
\text { Og }^{\prime}\end{array}\right|$ & ${ }^{\operatorname{In}} \mathrm{Ianp}$ & $\int^{\text {abbleat }}{ }_{c}$ & Remexte \\
\hline $\begin{array}{r}7: 55 \\
7: 56 \\
7: 57 \\
7: 58 \\
7: 59 \\
8: 00 \\
8: 01 \\
8: 02 \\
8: 03 \\
8: 04 \\
8: 05 \\
8: 06 \\
8: 07 \\
8: 08 \\
8: 09 \\
8: 10 \\
8: 15 \\
8: 20 \\
8: 25 \\
8: 30 \\
8: 45 \\
9: 00 \\
9: 30 \\
10: 00 \\
10: 30 \\
11: 00 \\
11: 30 \\
12: 00 \\
12: 30 \\
13: 00 \\
13: 30 \\
14: 00 \\
14: 30 \\
15: 00 \\
15: 30 \\
16: 00 \\
16: 30 \\
17: 00\end{array}$ & 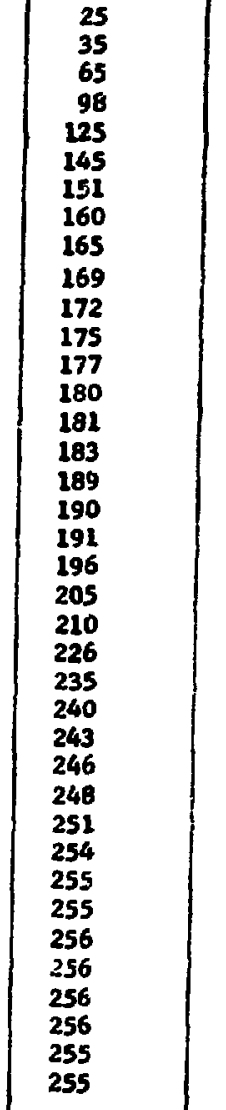 & $\begin{array}{l}25 \\
25 \\
25 \\
25 \\
25 \\
25 \\
27 \\
27 \\
27 \\
27 \\
28 \\
\\
30 \\
\\
31 \\
35 \\
35 \\
37 \\
40 \\
50 \\
57 \\
75 \\
75 \\
79 \\
80 \\
82 \\
83 \\
82 \\
83 \\
83 \\
80 \\
80 \\
82 \\
79 \\
79 \\
75 \\
\mathbf{p} \\
\end{array}$ & $\begin{array}{l}33 \\
33 \\
34 \\
32 \\
33\end{array}$ & 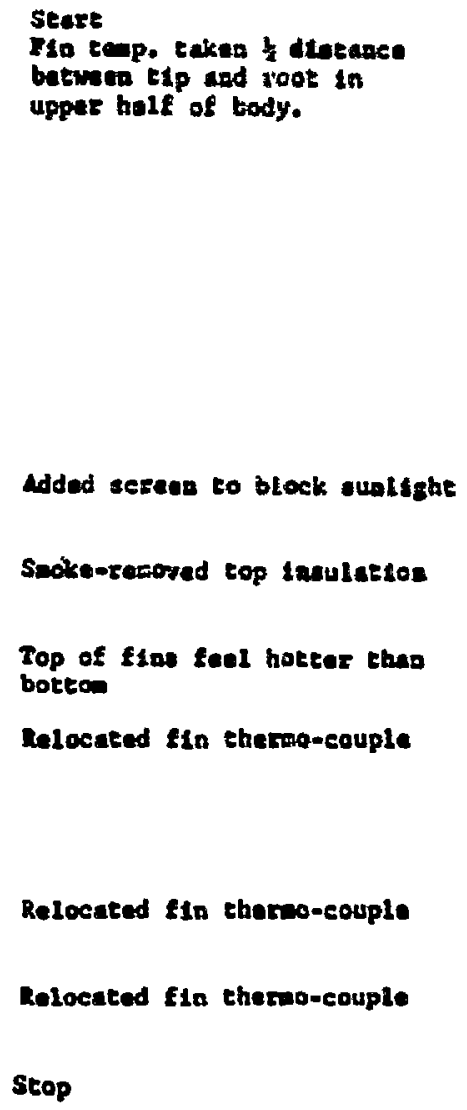 \\
\hline
\end{tabular}


BมตG-6 ap-8

II. E. Comprosaton stress

$$
\begin{aligned}
& \sigma_{c}=\frac{\frac{2000}{4} \frac{5.75}{2}^{2}-\overline{4.60}^{2}}{(\text { Sec Figure for II.B.1.) }} \\
& \sigma_{c}-107(p 51)
\end{aligned}
$$

This strest is insigniflcant compared to the allowable atress of 347 s. 


\section{F.1. Drop Condition Calculations}

1. Free drop to unyielding surface $\left(30^{\prime}\right)$.

a. Drop distance assumed to be $30 \mathrm{ft}$.

b. Weight assumed to be 200 lbs.

c. Worst possible condition assumed to be impact at corner of least structural mass positioned directly below center of gravity.

d. Fins and protective screen assumed to absorb no energy.

e. Inner container assumed to remain fixed with relation to outer container.

f. No energy absorbtion assumed due to plastic flow dynamics:

g. Elastic energy absorbtion assumed to be insignificant calculations substantiate this assumption at end of this section.

h. All energy is assumed to be absorbed by plastic deformation of container.

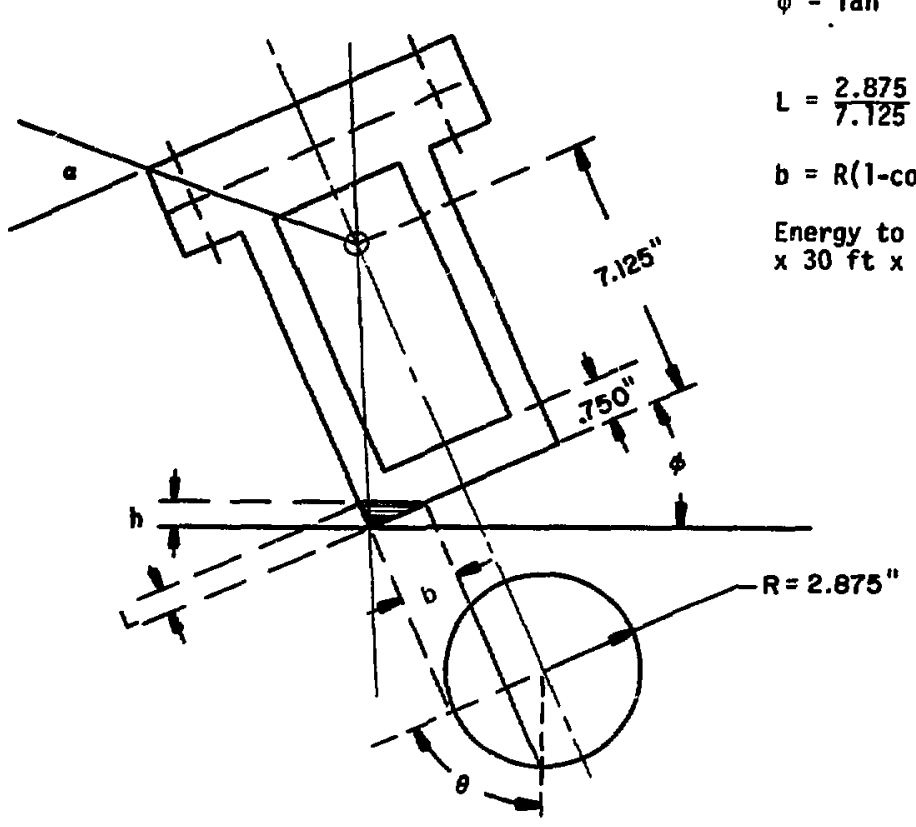




\section{II.F.I.(cont.)}

Plastic deformation assumed at lowest ultimate stress of $347 \mathrm{s.5}$. $\sigma_{u}=90,000$ (psi).

Volume deformed $=\frac{72 \times 10^{3} \mathrm{in}^{-1 \mathrm{~b}} \mathrm{~g}}{90 \times 103 \mathrm{ib} / \mathrm{in}}=.80 \mathrm{in}^{-3}$

$$
\begin{aligned}
V_{0} & =.80=\frac{R^{3} L}{b}\left[\sin \theta-\frac{\sin ^{3} \theta}{3}-\theta \cos \theta\right] \\
& =\frac{(2.875)^{3}\left(\frac{2.875}{7.125}\right)^{b}}{b}[]=\frac{(2.875)^{4}}{7.125}[]
\end{aligned}
$$

[]$=\frac{.80(7.125)}{(2.875)^{4}}=.08343$

For: $\theta=54^{\circ} 50^{\prime},[]=.817-\frac{.546}{3}-.958(.576)=.083$

$\theta=55^{\circ} 0,[]=.819-\frac{.549}{3}-.961(.574)=.084$

So for 1 imits of accuracy let $\theta=55^{\circ}-0^{\prime}$.

$\phi=21.6^{\circ}$

$\theta=55^{\circ}$

$b=2.875(1-\cos \theta)=2.875(7-.574)=2.875(.426)=1.225$ in

$L=.396 \mathrm{~b}=.396(1.225)=.485^{\prime \prime}$

$h=\cos \phi L=\cos 21.6 L=.930(.485)=.457^{\prime \prime}$

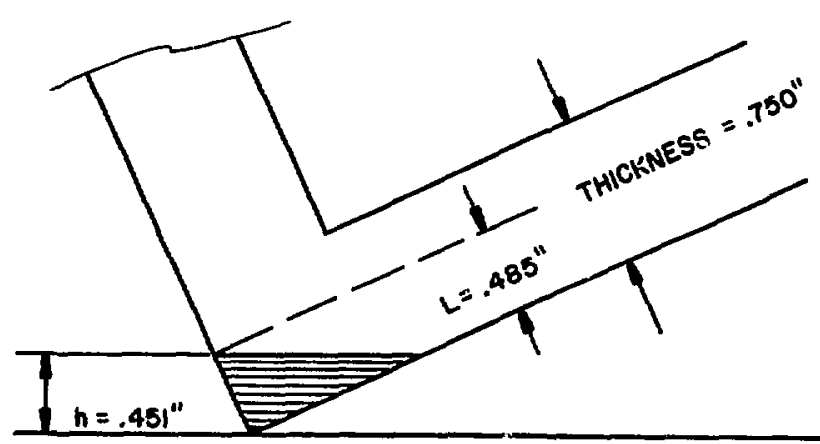

Plastic deformation ends with damage oniy to the outer edge, penetrating less than haifway through the material. 
II.F.1.(cont.)

Ref Item $G$.

Elastic Energy Absorbed:

yield stress of 347 (s.s.) assumed to be 35,000 psi

$F_{\max }=35,000(1.225 \times 2.50)=107,000 \mathrm{lbs}$

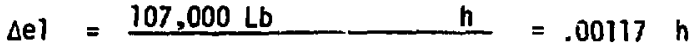

$3.06 \mathrm{in}^{2}\left(30 \times 10^{6} \mathrm{Lb} / \mathrm{in}^{2}\right.$

$=.00117(.451)=.000526$ in

Energy (Elastic) $=1 / 2(107,000 \mathrm{Lb})(.000526 \mathrm{in})$

$=28.12 \mathrm{Lb}-$ in

This is insignificant compared to 72000 in. - $7 \mathrm{~b}$ dissipated by plastic deformation so the assumption of only plastic deformation is valid.

\section{Bolt Stress:}

The worst condition for bolt stress would occur with the edge of the blind flange being directly beneath the c.g. at impact. This is at an angle ( $\alpha$ on sketch)

of $\tan ^{-1} \frac{4.92}{5.00}$ or $44.4^{\circ}$

$$
\begin{aligned}
& r_{s}=M a \cos \alpha=200 \frac{2(32.2)(30)}{2\left(. \frac{.41)}{12}\right)}\left(\frac{1}{32.2}\right)(.714) \\
& r_{s}=113100^{\#}
\end{aligned}
$$

1. Shear force $r$ sorbed due to friction between flanges,

Bolt tension assumed to be 17500 psi.

$M$ assumed to be .15 .

Total friction $=17500 \times 12 \times .142 \times .15$

$=4470$ Lbs which is negligible,

2. Shear stress on bolts.

Use high strength bolts as specified in ASTM A574-67.

Shear ultimate is 12,000 Lbs/bolt for $1 / 2^{\prime \prime}$ dia. bolts. 
II.F.1. (cont.)

Factor of safety $=\frac{12 \times 12000}{113,100}=1.27$

This indicates the bolts should not fail in shear.

Conclusion:

The only probable damage to the container should be some superficial plastic deformation. Considering the worst case together with rather-conservative assumptions, the damage (plastic deformation) penetrates less than half way through the outer container, therefore the inner container should remain undisturbed throughout all specified conditions. 


\section{II.F.3. Thermal Considerations}

Reference AECM 0529 Hypothetical Accident Conditions.

A thermal analysis was concluded on the $\mathrm{Pu} 238$ shipping container when exposed to a heat radiation envir.jnment of $\left(1475^{\circ} \mathrm{F}\right) 802 \mathrm{C}$ for thirty minutes. The Trump transient heat-flow computer program was used for this ourpose. A summary of the resulting temperatures, including material types and their melting points is shown in Fig. 2. The temperatures throughout the assembly approach the heat radiation environment of $802 \mathrm{C}$ by the time of conclusion of the test period. There is a slight valley in the vicinity of the inner vessel caused by the 250 Watt heat source contained within. (See Fig. 1.)

Since the melting points of the structural materials are well above the $802 \mathrm{C}$ temperature radiation environment, there is no capability of release of radioactive material form melting of of the containment vessel even though the assembly may suffer some superficial heat damage. The asbestos in the stainless steel-asbestos spiral-wound gasket of the outer vessel will decompose at $704.5 \mathrm{C}(1300 \mathrm{~F})$, however the seal will remain effective until the flange joint is braken by dissassembly. The silver solder braze joining the fins and outer container will meit during this 30 minute exposure, but fails to constitute a danger by release of radioactive materials. The arrangement of an inner and outer vessel containment assures that in the event of a severe impact preceding the heat radiation environment, all damage is absorved by the outer vessel. 


\section{II.F.3. (cont.)}

\section{CMB-11 PLUTONIUM SHIPPING CONTAINER}

Design Condition - Exposure to a temperature radlation environment of $1475^{\circ} \mathrm{F}(1075 \mathrm{~K}$ ) for 30 minutes with an emissivity coefficient of 0.90 .

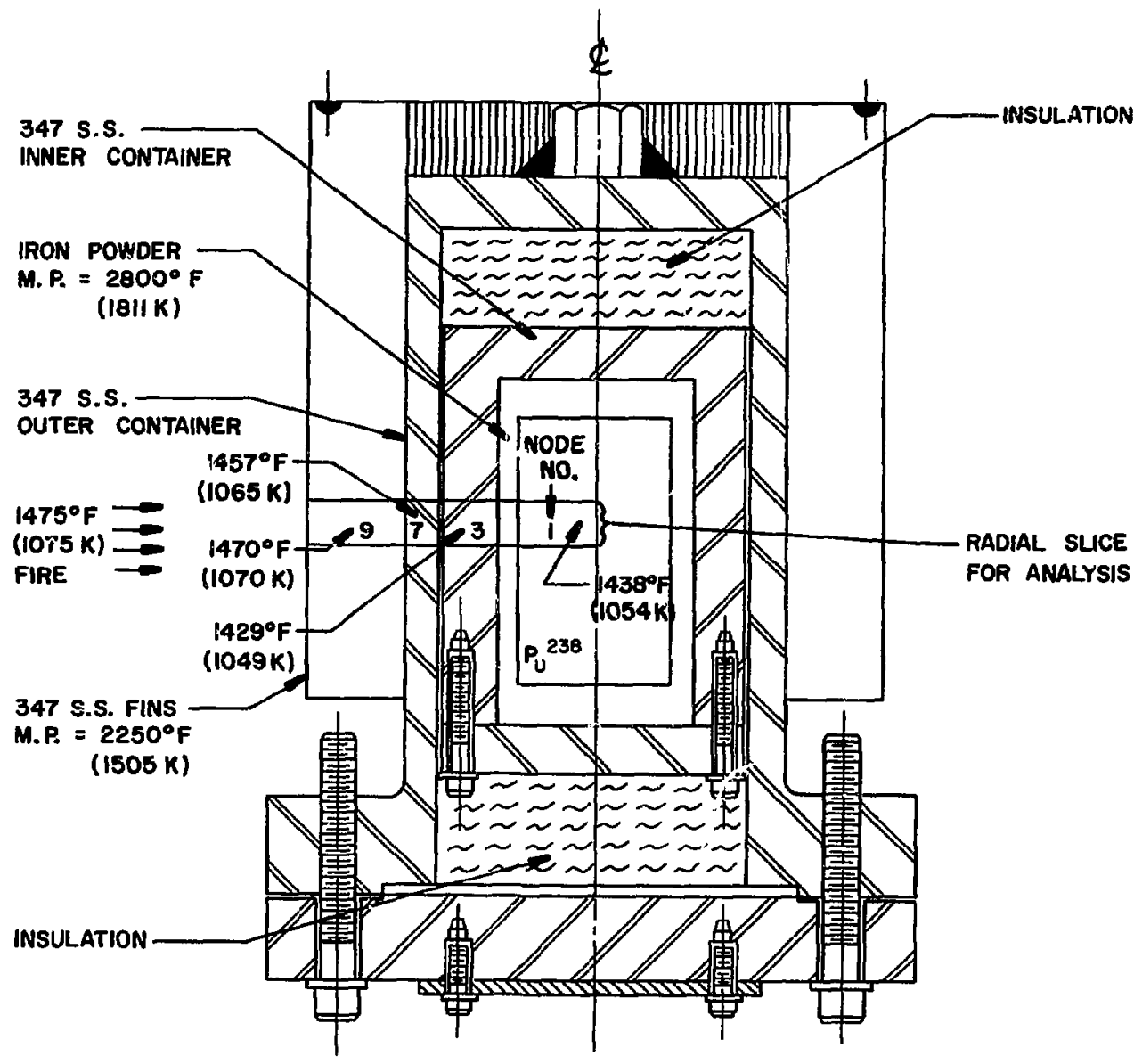

FIG. 2 . 
Radiation shielding was not the primary design criteria for the shipping container (DOT SP 6286). The source limitation of $750 \mathrm{gm}$ of plutonium, with no more than $520 \mathrm{gm}$ of ${ }^{238} \mathrm{Pu}$ was based on the heat dissipation from the 520 gm of ${ }^{238} \mathrm{Pu}$. The allowance of $230 \mathrm{gm}$ of other isotopes of plutonium is simply taking cognizance of the fact that pure ${ }^{238} \mathrm{Pu}$ is not the common form.

The primary radiation from the ${ }^{238} \mathrm{Pu}$ is neutrons and the emisgion rate depends on the exact chemical form. Considering a single chemical form, specifically $\mathrm{PuO}_{2}$, the neutron emission rate differs by as much as a factor of 10, depending on the ratio of oxygen isotopes. Since the neutron emission is not generally known, it is meaningless to attempt by calculation to show that the shielding will reduce the dose rates at the surface to $200 \mathrm{mrem} / \mathrm{h}$ and at three feet from the surface to $1.0 \mathrm{mrem} / \mathrm{h}$.

It is recognized by the shippers that radiation measurements made at the time of shipment must not exceed $200 \mathrm{mrem} / \mathrm{h}$ at the surface nor $10 \mathrm{mrem} / \mathrm{h}$ at three feet, and that compliance with these radiation levels may impose lower mass limits on the quantity of ${ }^{238} \mathrm{Pu}$ which may be shipped. 
No exception is made to applicable external radiation levels. Inner containment requires double encapsulacion of tha source material, and the outer walls of the doubly encapsulated source are swipe-free before loading into the shipping container cavicy. Early calculation was very conservative in assigning radiation levelo to ${ }^{238} \mathrm{PuO}_{2}$ and subsequent measurenents have show such levels to be well within grescribed 11mits. For example, the current fuel module used by Sis/AEC is a 100-W sphere approximately $2.7 \mathrm{~cm}(1.5 \mathrm{in.})$ in diameter. The following radiation measurements were made on January 22,1974 , on such a sphere inside a DOT-6286 shipping container.

$\begin{array}{ccc}\text { Position of Detector } & \frac{\begin{array}{c}\text { Bcta-Ganma } \\ m r / h\end{array}}{1.5} & \frac{\begin{array}{c}\text { Neutrons } \\ \text { mreg/h }\end{array}}{15} \\ 0.9 \mathrm{~m}(3 \mathrm{Et}) & 0.2 & 3\end{array}$

These lavels are well below the 200 mrem/h (total beta-gama + neutrons) at contact and $10 \mathrm{mrem} / \mathrm{h}$ at $0.9 \mathrm{~m}$. Even if two spheres were packaged in one concalner, the 200 mrem limit would not be approached. Dirensional limitations would not permit wore than two spheres in the inner cavicy.

The reciplent of a radioactive shipment is provided with the following information prior to or at the time of shipping.

a. Appropriate sketches showting the containers used in packaging, and identification and location within the containers of their contents.

b. An assembly drawing of the shipping cask. A photograph way also be supplied if required.

c. Any rechnical detall regarding the encapsulated samples, such as the contamination level of the inner containers, beta-gamma acrivity levels of the samples, and physical conditions of the samples are discussed with the reciplent prior to shipient. 


\section{NUCLEAR CRITICALITY SAFETY EVALUATION FOR}

SHIPLENT OF PLUTONILM-238

The assumption was made that the recently designed shipping container, Drawing ENG-E 324 (D1-D4), would be used for shipment of plutonium in quantities not to excees

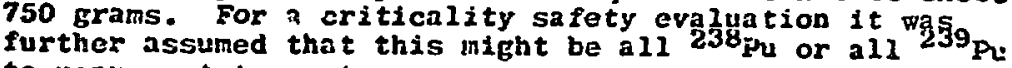
to rapresent two extreme cases.

The volume of the cavity in the inner container (Part No. 4) is approximately $660 \mathrm{cc}$, which corresponds to a spherical radius of $5.4007 \mathrm{~cm}$. The thickness of stainless steel radially and arialiy about this cavity provides a volume of steel of 3.005 liters, neglecting fins, bolts, flanges, etc.

Spherical cells were calculated wi th the DTF IV code l:cing tho S.: spprci:t:ation. Stainless steel was placed in a spherical shell from $5.4007 \mathrm{~cm}$ radius to $9.5637 \mathrm{~cm}$ radius, to provide the volume of 3.005 liters of steel. The inner cavity was filled uniformly with low density $(i .137 \mathrm{~g} / \mathrm{cc}$ ) plutonium to prortde a net plutonium loading of 660 grams. The outer boundary of the cell was made reflecting, to simulatio an infinite array.

Then the cell was loaded with plutonium 238 , the $k$ value for an infinite array was found to be 0.58 . Replacing the 238 pu with 239 pu resulted in a $k_{\infty}$ value of 1.073 . Next, the steel was surrounded by $0.44-\mathrm{cm}-$ thick water to check the effect of inter-unit moderation. The value of $\mathrm{k}_{\infty}$ for the ${ }^{239} \mathrm{Pu}$ loading was now found to be 0.53 . The corresponding value for $238 \mathrm{pu}$ would be even lower.

A fourth calculation was performed to determine the thickness of steel required for an infinite array to be critical with the $239 \mathrm{Pu}-\mathrm{filled}$ cavity. The resulting radius for the outside of the steel was $9.8974 \mathrm{~cm}$, for a volume of steel of 3.401 i1ters corresponding to $26.74 \mathrm{~kg}$ or $58.8 \mathrm{lbs}$.

The actual weight or steel in a package should be more than 150 lis, so there is sufficient steel in a

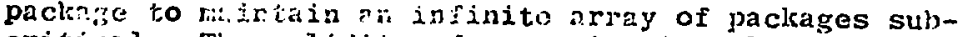
critical. Tili validity oj averaging in all the steel in a paciage 1 s indicatad ly consicleation of the size of a barc criticil aray at the averafe density of plutonjum in tho cell, troring ine jresence of steel. 
Such an array would be more than 200 feet in each dimension. The presence of steel reduces the $k_{\infty}$ from about 2.9 (for pure $239_{\mathrm{Pu}}$ ) to below the calculated 1.073. This implies that neutrons would traverse many cells in an array before being absorbed and would therefore tend to "average out" the gross inhomogeneities in the steel distribution in the individual cells.

The assumption of uniform low density for the plutonium in the cavity is conservative, in that lumping the plutonium to metal density would reduce the multiplication factor of the array.

The presence of other isotopes of plutonium (240, 241,242 ) would not increase the multiplication factor above that for $239 \mathrm{pu}$.

Since fc: tine proposed loading an infinite array of these containers would be sub-critical, either as prepared for shipment or as damaged through exposure to the hypothetical accident of $A E C M$ 0529, these containers comply with the criteria for Fissile class $I$. 
QUALITY ASSURANCE PROGRAM PLAN

FOR

OMB-II PLUTONIUM SHIPPING CONTAIHER

LAB JOB 4424-0

1. Scope

This document sets forth the elements of a program for quality assurance and methods of quality control and verification which will be used during the design (review), operation and maintenance phases of the Plutonium Shipping Contoiner, CXB-11, hereinafter called the Container. The quality assurance program presented in this document is based on meeting the requimements of the LASL Quality Assurance Program Manual (I.ASL unclassifled release LA-UR-73-603), including all supplemental Quality Specifications (e.g., Quality Assurance Requirements, QAR's, and Quality Assurance Instructions, $Q A I^{\prime} s$ ).

The container is intended for the shipment of Pu-23B metal/oxide. The operating organization for the container will be CMB-1l.

2. Quality Program Elements and Actions

The Quality Assurance Program for the container will be in accordance with the "LASL Quality Assimance Program", including the Quality Assurance manuals, designs, documentation, procedures, inspection and other activities pertatining to quality assurance of all organizations performing quality functions for the project.

The consequence-of-fallume for the container has been established as Type I (failure could cause an incident affecting public health and safety) and its component complexity category is I (simple parts). The Component Quality Assurance Level Classification for the container is therefore $\mathrm{C}$. Table 1 lists the Quality Assurance activities required for the container.

3. Organization

The requirements of this document will be imposed on all organizations performing work on the container. Services of other groups will be required to carry out profect functions including, but not limited to, those listed below:

\section{Function}

Design

QA Design Review Board

Operation Administration

\section{Onganization or Individuals}

LASL Engineering Department $\mathrm{CM}-11$

QA Design Review Board

See LASL Internal Supplemental Inf ormation Bulletin

GM-II

4. Documentation

A. Records Accumulation and Retention

All Quality Assurance documentation shall be retained in the

"QA Bindez" of the Lab Job 4424-0 Folder or, in the "QA files" of group CMB-11. The lab job is an internal Engineering

Department numbering system that allows documentation for any given profect to be filed and retrieved. 
Table 1

QUALITY ASSUPANCE ACTIVITIES REQUIRED FOR CONTAINER

Management

Quality Assurance Planning

Quality Assurance Records, Accumulation, Retention, and DIstribution

Design

Design Criteria

Design Review

Fallure Study

Operation and Maintenance

Document Control

Operator Training and Qualification

Controlled Operating Procedures

Controlled Maintenance Procedures

In-Service Inspection Program

Fallure and Incident Report

Corrective Action 
LOS ATAAOS SCIEWTIFIC IAEORATORY ENGLNIEERIIG DEPARTULWT

WELDIIG SPECIFICATION ZNG-6 Sp-8

\section{$1.0 \quad$ FURPOSE}

1.1 The purpose of this specification is to govern the welding of corrosica resistant steels, aluminum alloys, and carbon and low alloy steels.

2.0 SCOPE

2.1 This specification covers the requirements for process control, inspection, anci acceptance of welds of corrosion-resistant steels, alurinum alloys, and carbon and low elloy steels. Use of manual, semiautoratic, and autcmatic technicues are within the scope of tinis specification.

2.2 Drawing references to particular welds and callout of particular processes will be in adition to the requirements of these specifications.

\subsection{APPLICABIE DOEUMENTS}

3.1 MIL-STD-410, "Certification of Penetrant Inspection Personnel".

3.2 MIL-I-6866, "Inspection, Penetrant Kethod of."

3.3 MIL-I-6868, "Inspection Process, Nagnet1c Particle".

3.4 NII-C-7701, "Certification of Magnetic Particle Inspection Personnel".

3.5 American Society of Mechanical Engineers, Boiler and Pressure Vessel Code, Sections VIII and IX.

3.6 AHS We?ding Handbook (Welding Symbol Interpretations).

4.0 RESUIREMEITIS

4.1 Gualification and Certiflcation of Welders.

4.1.1 Welders and welding operators using manual, semiautomatic, and automatic equipment shall pass qualification tests and be certified per the ASM. Boiler and Pressure Vessel Code, Section IX, for the applicable material thickness, alloy, and process.

4.1.2 The supplier shall furntsh evidence of such qualification to the buyer. 
4.2.3 Tre welding procedure to be used by the supplier shall be submitted to the tuyer for aporoval. In aidition to standard 1tems, this procedure shall specify a list showing which riller materials will be used on each alloy, or combination of alioys as called out on the drawings of parts to be welded. Also included shill be a detailed description of the cleaning proceaure to be usea before welding.

4.1.4 The velding equigment used shall be capable of consistently producing setisfactory welos, when used by a competent operator.

4.2 Geld Precaration

4.2.1 All scaie, slag, grease, oil, rust and other foreign ratter shall be reroved fron the area rithin four incies on both sicies of the welding zone before velding is swarted.

5.0 GUALTIY ASSLRALCE FRCVESICTE

5.1 All flux, slag, and spatter shall be thoroughly removed from the weldrent oefore final inspection.

5.2 Weldments shall be inspected after eny heat treatment and prior to machining or surface finishing operations which might obscure defects.

5.3 Evidence of lack of control over the welding process, poor workmarship, or poor appearance shall be cause for rejection by the buyer's inspector.

\subsection{Inspection - Ciass I}

5.4.1 Unless otherwise specified on the product drawing, the inspection requirements for class I welis shail be (1) 100 percent visuel, (2) 100 percent masnetic particle or penetrant, end (3) 100 percant radiographic inspection of eech weldment. Limits or imperfections in acceptable wiclds are show in Table I. Magnetic particle and penetrant inspection shall be in accordance with MIL-I-6868 und MIL-T-66́́, respectively. Wegnetic particle and penetrant inspection personnel shall be certified in accoriance with MIL-C-77Cl or MIL-STD-410, as applicable. Radiographic inspection shail be in accordance with Para. Ui-51, Section VIII of ASME Pressure Vessel Code.

\subsection{Inspection - Class II}

5.5.1 Unless otherwise specified on the product drawing, the inspection requirements for Class II welas shall be 100 percent visual. Limits of imperfections in acceptable welds are shown in Table II. Magnetic 
5.5.1 particle and penetrant inspection, if reguires, shail be in accoriance with MIL-I-6268 and MII -I-6866, - espectively. Magnetic particle and penetrant inspection $\%$. onnel shall be certified in accorciance with MIL-C-?70I or $: I I L-S T L-410$, as applicable.

\subsection{Repair of Defects}

5.6.1 Repair of defects is permissible if the reoairei weldment, the repeir vield itself, and the adjacent parent retal meet the recuirements of the original weldment. A repairej *elorent shall be reinspected in the same manner as the orifinal veiurent.

6.0 CARBCN AIT LON ALLOY ETEEI

6.1 Method

6.1.1 Welding shall be done by any of the are weiding processes or by the oxyacetylene process where applicsole.

6.1.2 Bevelint anc weld preparetion may be done by any conventional means including oxyacetylene cutting, proviced precautions are taken to prevent cracking.

6.1.3 All low alloy steels having a carbon content greater than 0.25 percent and carbon steels having a carbcn content greater than 0.35 percent sinall be preneated to, and :mantained at, a minimum temperature of $350^{\circ} \mathrm{F}$ during welding.

6.1.4 Helds shall be cooled no more severely than by still air at room temperature.

\subsection{Repair of Defects in Heat Treated Parts}

6.2.1 Weldments that are heat treated after welaing ray be repairwelded only after reduction to a strength level lower than 125,000 psi tensile ultimate and provined that heat treatment follows repairing.

7.0 CORROSION RESISTANT STEELS

7.1 Nethod

7.1.1 Welding shall be done by any of the arc welding processes.

\subsection{Repair of Defects in Heat Treated Parts}

7.2.1 Weldments that are heat treated after welding ray be repairwelded only after reduction to a strength level lower than 125,000 psi tensile ultimate and provided that heat treatment follows repairing. 
ENG-6 Sp-8

\subsection{ALUN:IIUM \\ 8.2 Nethod}

8.1.1 Welding siall be cione by the inert-gas-shielded retal arc process using a consuriole electroce, or the ineri-gas-shieldied tungsten arc process. 
CLASS I VELDS

TABLE I

LIMITS OF TR:PERFECTIONS IN ACCEPTABLE WELDS

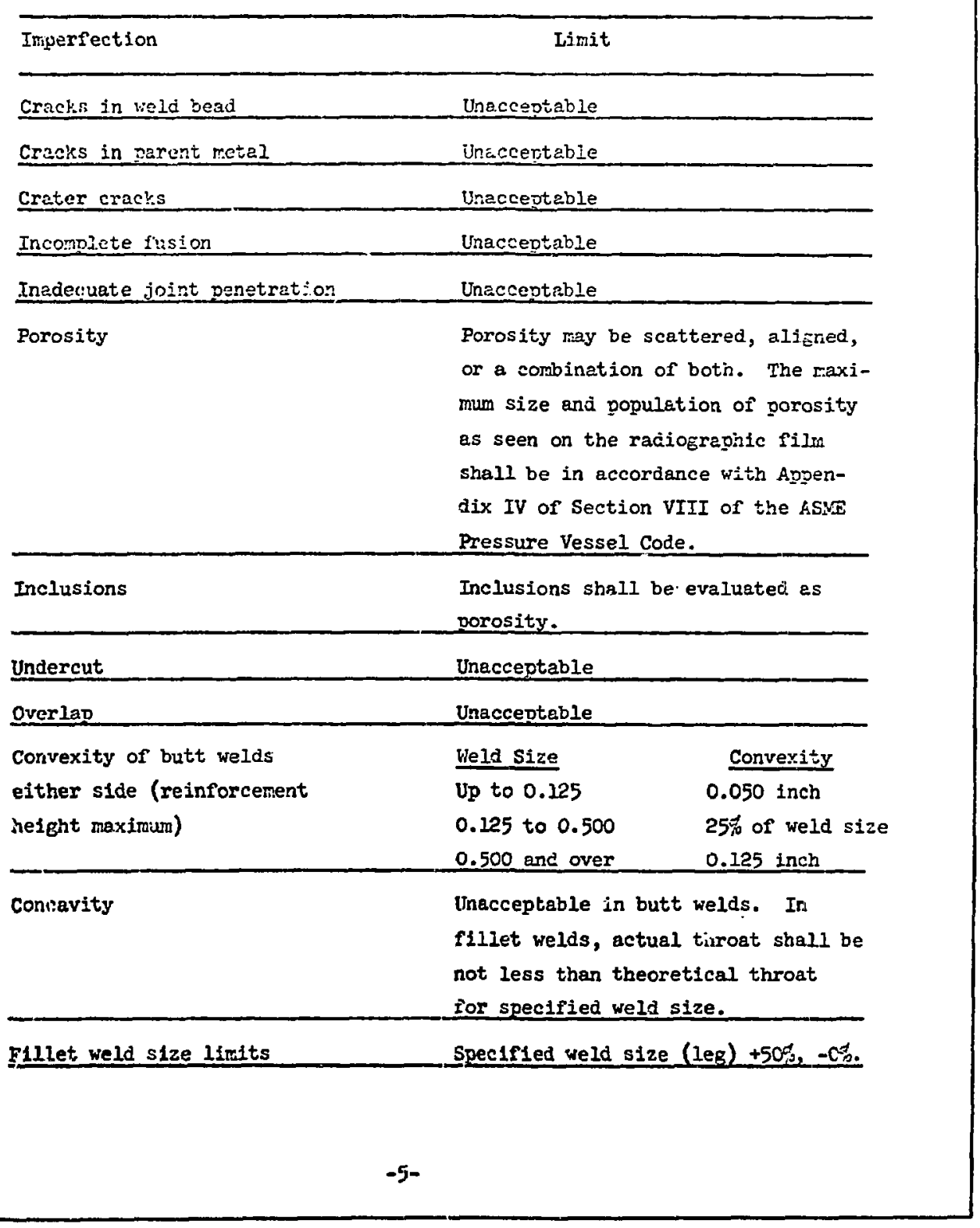


CLASS II WELDS

TABLE 2

LIMITS OF IMPERFECTIONS IN ACCEPTABLE WELDS

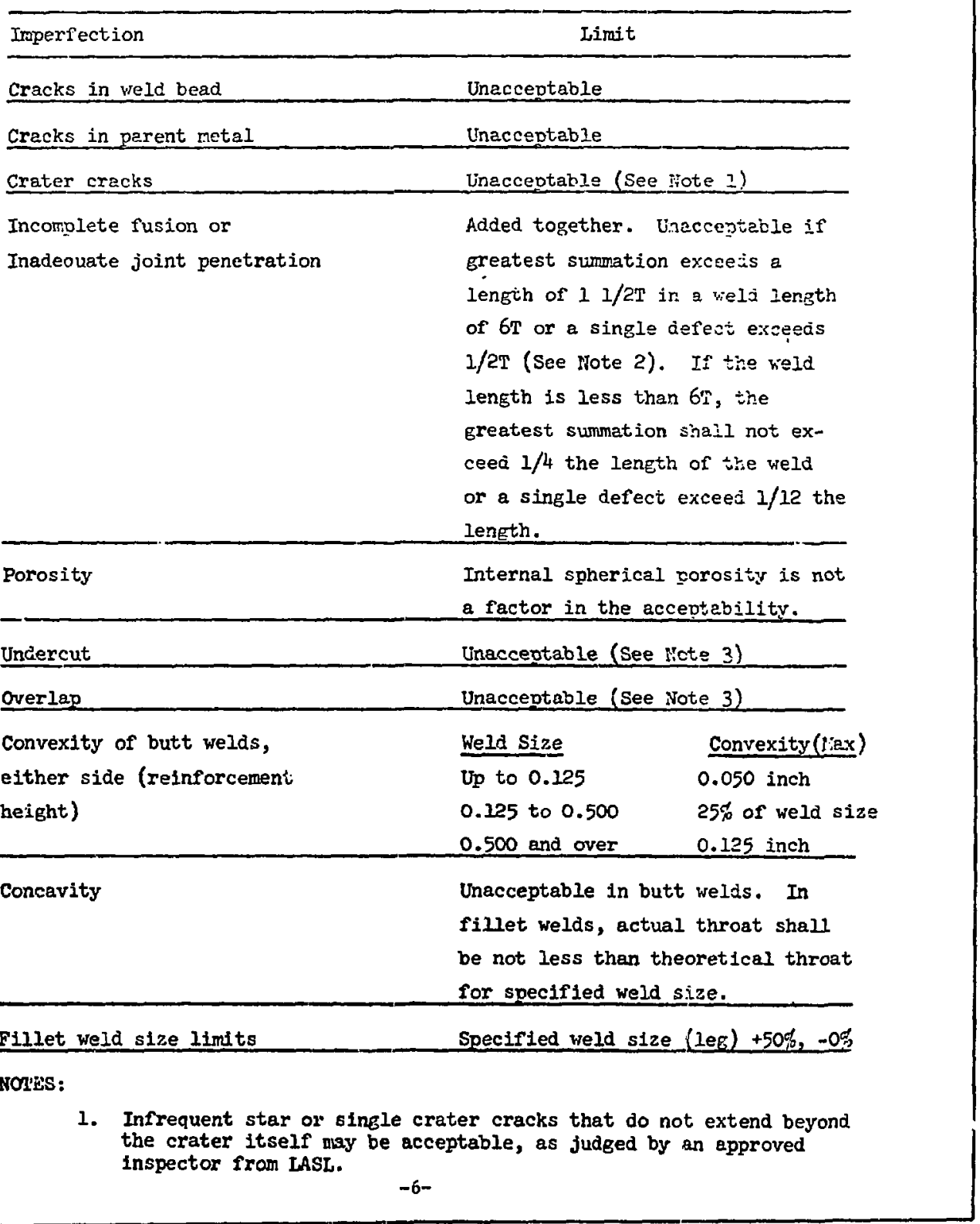


ENG-6 sp- 8

\section{CLASS II MELDS}

TABLE 2

NOTES: (Continued)

2. ( $\mathrm{T}$ ) is the specified weld size.

3. Infrecuent undercut and overlap may be acceptable, as judjed by an approved inspector from LASL.

$-7-$ 
U.S. ATOMIC ENERGY COMMISSION CERTIFICATE OF COMPLIANCE

For Radioactive Materials Packages

\begin{tabular}{l|l|l|l|l}
\hline $\begin{array}{l}\text { 10. Number } \\
\text { AEC -AL }\end{array}$ & USA $/ 6286 /$ B LF & $\begin{array}{l}\text { Do. Revision No. } \\
\text { Origina I }\end{array}$ & $\begin{array}{l}\text { te. Page No. } \\
1\end{array}$ & $\begin{array}{c}\text { 1d. To1:1 No. Pages } \\
1\end{array}$ \\
\hline 2. Authority
\end{tabular}

This certifirate is issued pursuant to Sections 173.394, 173.395, and 173.396 of the Deparment of Transportation Hazardous Materials Pegulations as amended (49 CFR 170.189 and 14 CFR 1033, and AEC Manual Chapters 5201 and 0529.

3. CONDITIONS

3a. This certificate is issued on the batis of SAFETY ANALYSIS REPORT FOA PACKAGING ISARP)

(1) Prepared by
David R. Smith
Thomas $K$, Keenan
J.N.P. Lawrence
Horace E. Noyes

(2) Number

(3)

3b. The packaging described in the SARP and further described in item 4 below, when construeted and assembled as prescribed in the SAAP. with the contents as authorized herein, meets the standards prescribed in DOT regulations.

3c. The outside of each package must be plainly and durably marked with the letters and number shown in item 19 . on this torm in accordance with the standards for markings in paragraph $173.241 \mathrm{bl}$ of 49 CF 173.

3d. This certificate does not retieve the consignor fro,n compliance with any requirements of the regulations of the U.S. Department of Trensportation or other applicable regulatory agencies.

3e. Eech user of peckages approved under this certificate shali register his name and address with the issuing office.

4. Description of Packaging and Authorized Contents, Restrictions, and References:

a Description - Tnis container consists of a cylindrical stainless steel weldment witn external cooling fins. It contains internal neat dissipating materials surrounding the central cavity. The cask body is mounted to a base/closure assembly and enclosed witnin an outer steel mesh cage. The package is approximately 18 inches in diameter by 20 inches high and weighs about 200 pounds. The package Is ldentified as the CMB-11 P1utonium Shipping Container and is described in LASL drawings ENG-E 324-D-1 tnru D-4.

b. Authorized Contents - Contents must be doubly encapsulated and not exceed 750 grams of Plutonium (Oxide or Metal) or be so reduced in quantity as not to exceed applicable external radiation limits at contact and one meter. Heat load of the contents is not to exceed 250 watts. Container and contents a limited above meets the requirements for shipment as Fiasile Class I.

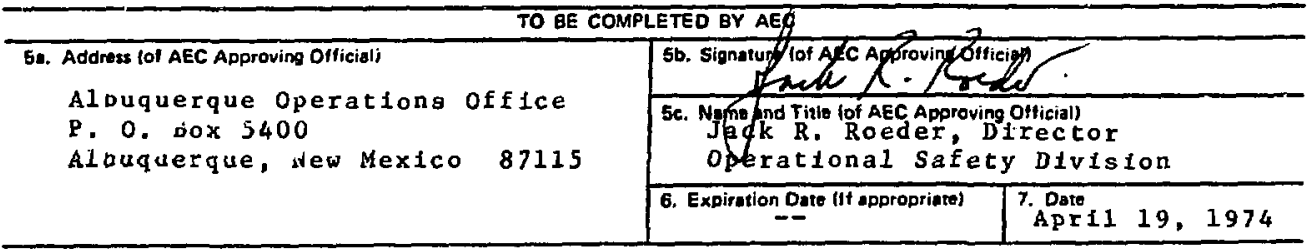


These drawings are available from the National Technical Information Service, U.S. Department of Commerce, 5285 Port Royal Road, Springfield, VA 22151. 


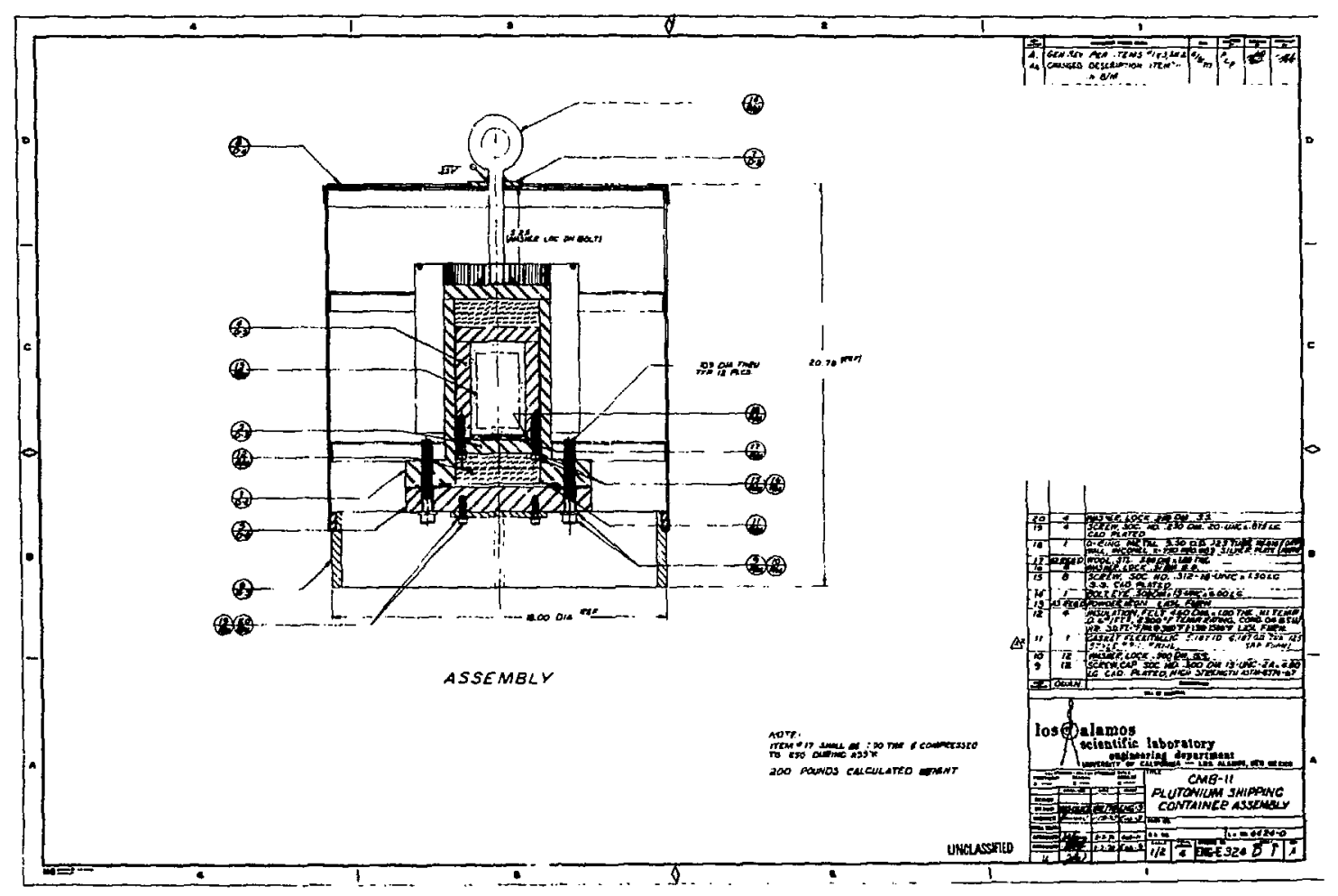




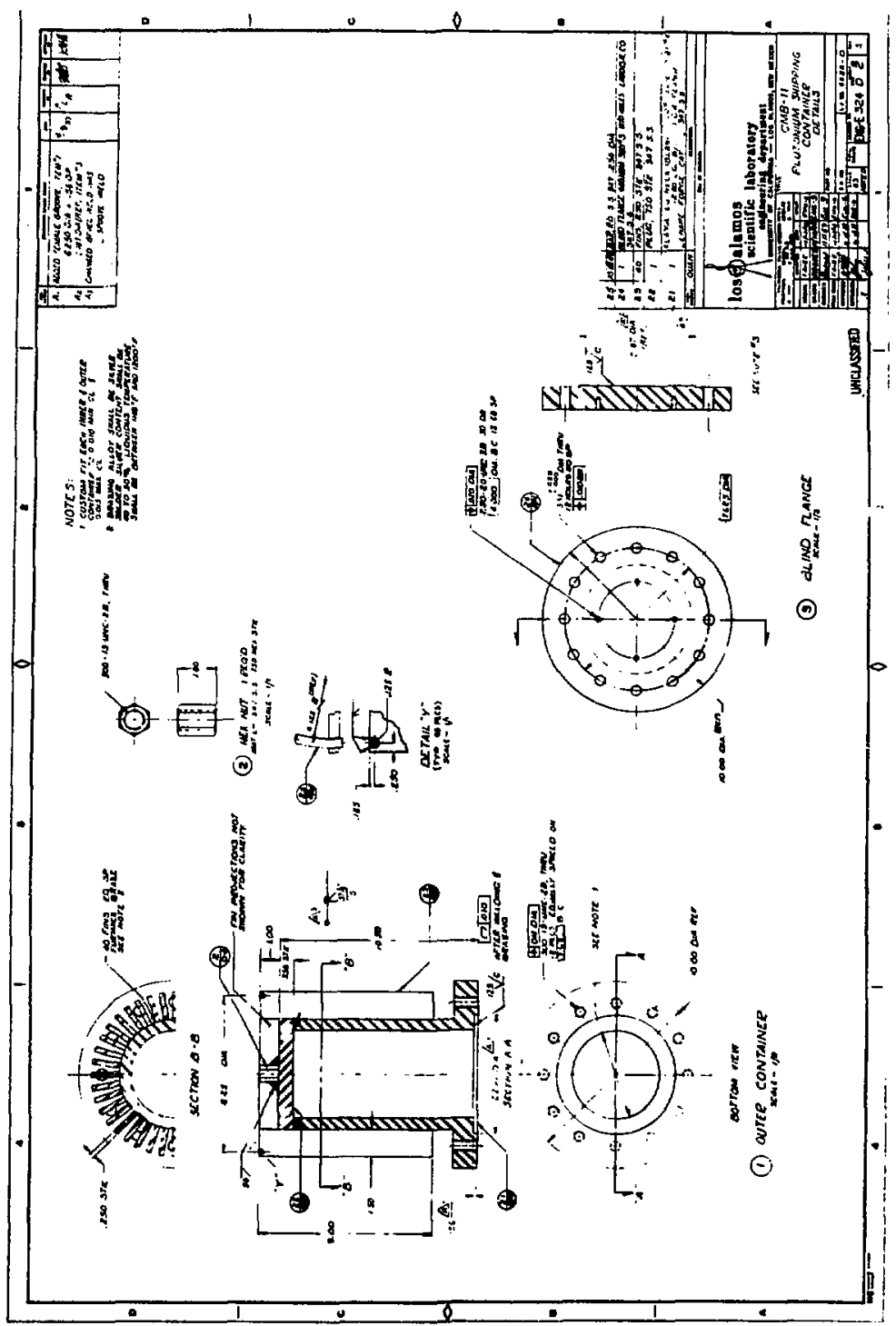




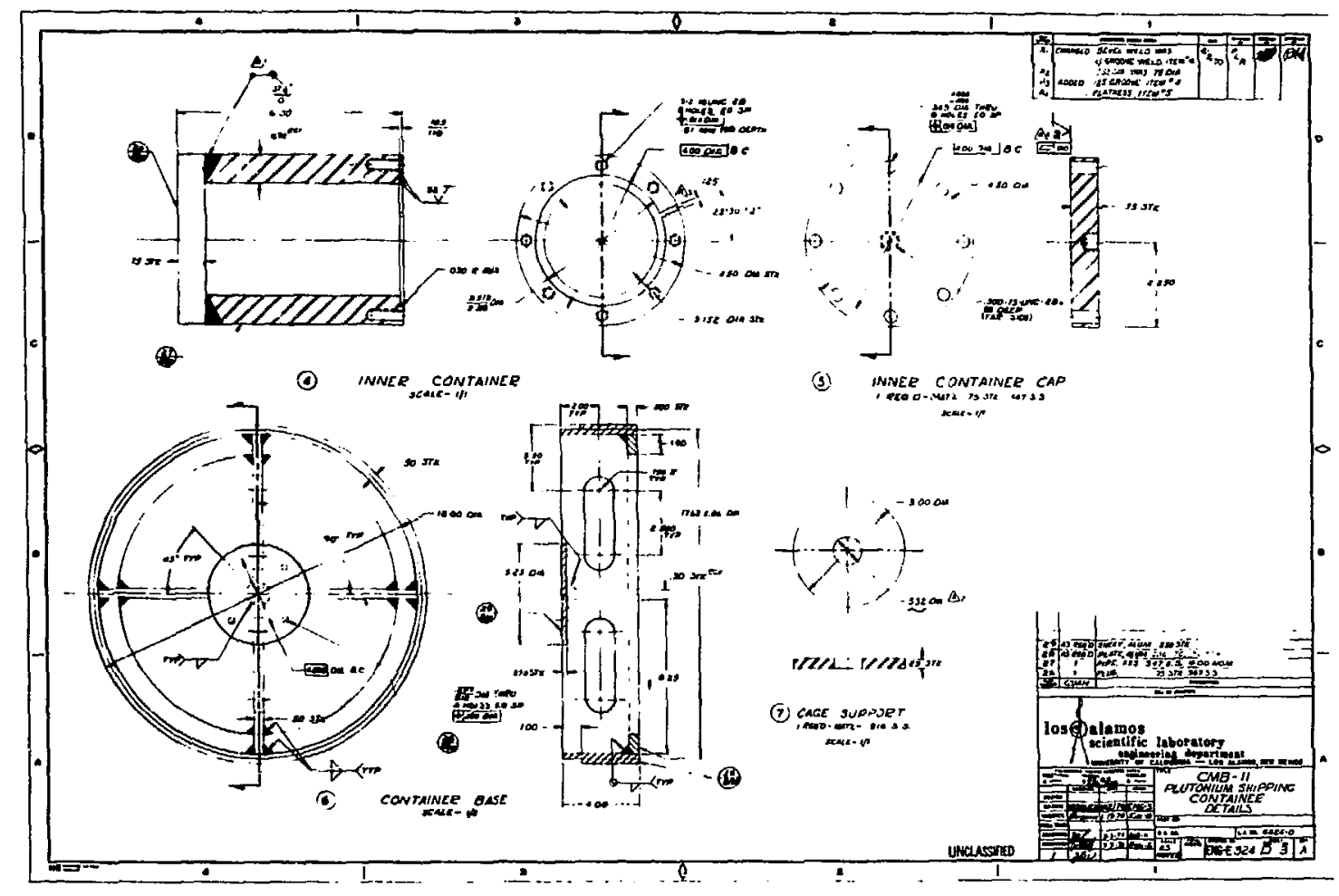




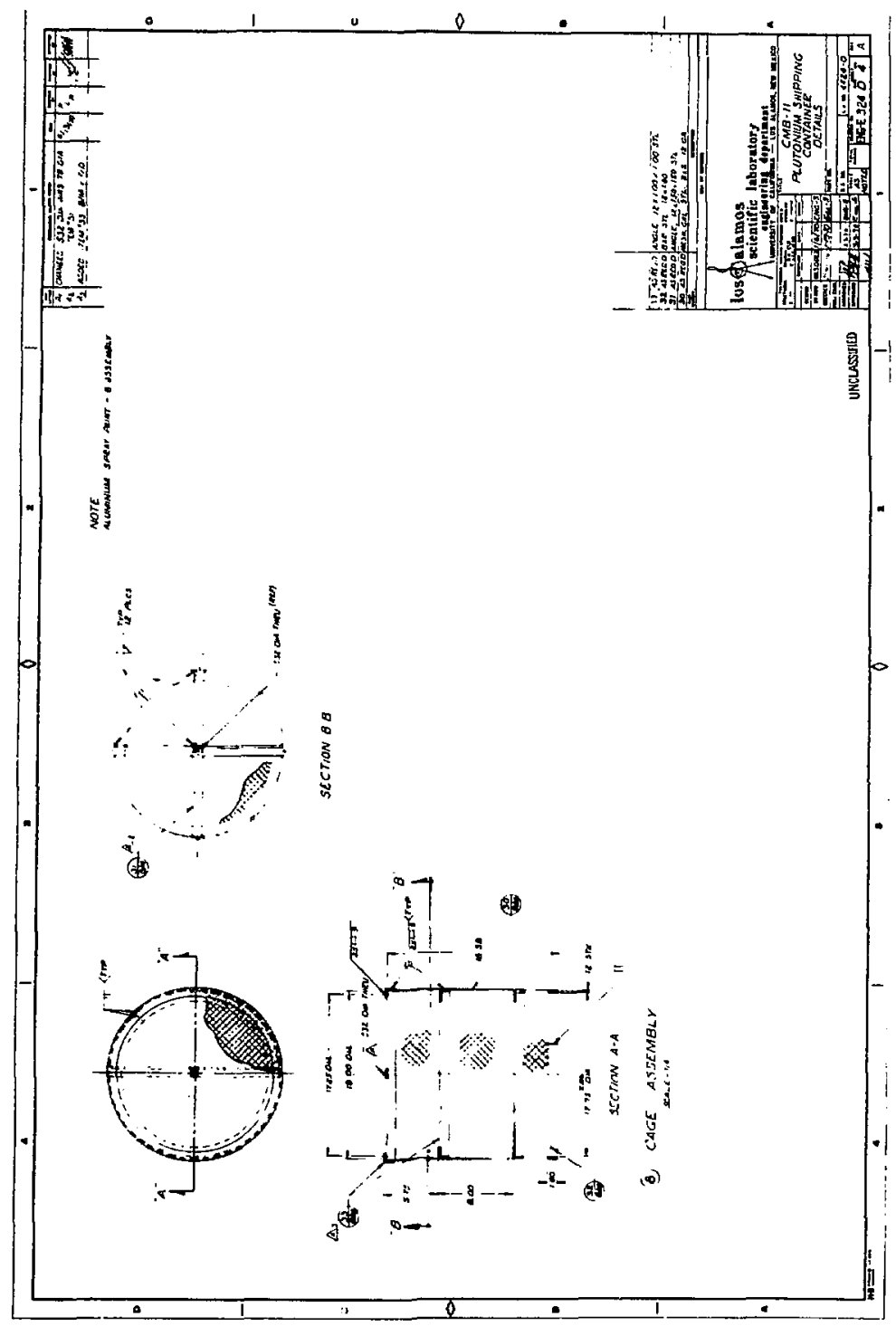

\ UB GOVEANMENT PFINTINE OFFICE: 1074 - 784-630/6E

EE: 424(30) 